\title{
Moral Luck
}

\begin{abstract}
The concept of moral luck appears to be an oxymoron, since it indicates that the right- or wrongness of a particular action can depend on the agent's good or bad luck. That goes against the reasonable assumption that the moral quality of our conduct, the praise- and blameworthiness of what we do, should only hinge on factors that are within our own control. It seems unreasonable to let the moral verdict of someone's decision and action depend on whether the outcome happens to be good or bad, particularly in situations where luck plays a significant part in how things turn out. In organizational life, moral luck nevertheless is a recurring phenomenon, in that actual outcomes do affect our moral evaluations of what people do. A reckless person can get away with his or her moral gamble if the outcome is good, but will get severe criticism in the likely event of a bad outcome. This chapter explores how moral luck connects to the normative theories of duty ethics and utilitarianism, and the extent to which moral evaluations based on actual outcomes are acceptable.
\end{abstract}

Keywords Moral luck • Act utilitarianism • Rule utilitarianism • Resultant moral luck • Situational moral luck • Relational moral luck

An entrepreneur needs backing from his investors to start a business venture in the far north of Norway. The venture will provide much needed activity in the local community, and create hundreds of jobs to people who 
have been unemployed for a long time. One key element in the story the entrepreneur has told his investors is that he will have a strategic relationship with a multinational customer from day one. The day before finalizing the investment, the customer announces that they are backing out. If the entrepreneur informs the investors about this negative development, they are likely to withdraw from the project. Should he nevertheless tell them now, or wait until the first board meeting, after the money from the investors is in the bank?

The entrepreneur can turn to duty ethics and utilitarianism for guidance in this situation. From a duty ethics perspective, to keep the investors out of the information loop is morally unacceptable. It does not help that the outcome is likely to generate work and be good for the local community. Duty ethics encourages the decision-maker to consider how he would want anybody else in a similar position to behave. Would it be morally acceptable if all entrepreneurs withheld information from their financial partners in such situations? No, is the answer coming from duty ethics, since no rational person can will that deception becomes the standard way to act in such situations, without becoming inconsistent, making exceptions for himself or herself. Furthermore, the act of keeping crucial information from the investors would be an example of using them as mere means to achieve financial success and create jobs, and as such, it would be morally unacceptable from the perspective of the humanity formulation of the categorical imperative.

A utilitarian can see things differently, and will take into account that the project will create important jobs and activity in a poor community. Keeping the information away from the investors might be necessary in order to maximize utility for all concerned, and promote the common good. However, the case can illustrate a split among the utilitarians. Some of them share the duty ethical concerns about universality. What if everybody in business started to keep information away from their own investors and business partners? That would create environments of distrust, and cause bad outcomes in the long term. Other utilitarians are not concerned about this aspect of the situation, and focuses instead on the here and now. The split in the utilitarian ranks is real. One fraction is called rule utilitarianism, and it proposes a two-step decision-making process: First identify the rule of action that will generate the most utility and common good in situations like these, and then act in accordance with that rule (Brandt, 1959). This utilitarian fraction agrees with duty ethics in the entrepreneur case, and advises him to be transparent and open with the 
investors, since that would be to follow the rule most likely to maximize utility in such situations. If every entrepreneur started to keep bad news from their investors, it is likely that it would have created mistrust in their relations, and the overall outcome would have been negative. The alternative theoretical fraction is called act utilitarianism, and it maintains that the simple principle to follow is to choose the available course of action that will maximize utility (Brandt, 1959). The entrepreneur should keep the information about the customer withdrawal to himself, since openness would jeopardize the project to create jobs in the far north of Norway. This should not be mistaken for an egoistic argument, since it is out of concern for the common good and the inhabitants of the local community that it would be right for the entrepreneur to keep the information to himself.

The story about the entrepreneur and his investors continues. He decided not to share the information about the loss of the customer to his investors, and the project gets underway. New customers arrive quite early in the process, and the project becomes a success, creating profits for the investors and new jobs for local people. The business venture was the starting point for social development and growth in the community. Hundreds of people now have a good income and can remain with their families in their local community. At the ten-year anniversary of the project, the entrepreneur drew attention to the opening incident, when he was in serious doubt about telling his investors or not about the customer withdrawal. Now he can look back and be relieved that he did not follow the moral intuition to be open and transparent with the investors. To this day, he is convinced that they would have taken their money elsewhere if he had told them about the negative development. The project would have collapsed, and there would have been no new jobs in the local community. He believes that the actual positive outcome justifies the decision to keep quiet. He thinks that the overall consequences in terms of benefits to the local community prove that he was right in doing so.

The extent to which we agree with the entrepreneur's evaluation depends on our stance on what we can call moral luck. The philosophers Thomas Nagel (1979) and Bernard Williams (1981) introduced the concept of moral luck, with the intention of identifying a tension in our moral reasoning. On the one hand, we believe that morality is immune to luck, in the sense that people are only morally responsible for aspects of their behavior that have been within their control. It seems unreasonable to blame or praise someone for actions and outcomes that largely 
have come about through a set of fortunate or unfortunate circumstances. On the other hand, the actual outcomes of what people do tend to color our evaluations of their conduct. Theoretically, we may be convinced about the moral irrelevance of luck, but in practice, we discriminate and judge based on actual outcomes (Lench, Domsky, Smallman, \& Darbor, 2015).

One domestic example that has been used to illustrate moral luck is that of drunk driving (Hartman, 2017, 2018; Zimmerman, 1987). Two guests who have drunk considerable amounts of alcohol at a party may both foolishly decide to drive home in their cars. They are equally to blame for exposing other people to the risk of serious harm and death. One drunk driver gets home safely without hurting anybody, while the other hits and kills a pedestrian while driving on a red light at a street crossing. The former is likely to get off more lightly than the latter, both legally and morally. From a legal perspective, it makes sense to distinguish between the two cases, but morally it seems that both deserve equal amounts of blame and criticism. Both have put other people at risk, in exactly the same manner. In general, we can be convinced that there is no morally relevant difference between the two cases, but in reality, it is commonplace to distinguish between them, and even shrug at the former driver's behavior. There seems to be an unsatisfactory imbalance, then, between our moral theory and our moral practice.

Michaelson (2008) has studied moral luck in a business context, using as his main example the pharmaceutical company Merck and their development of medicine to cure river blindness, a plague affecting millions of poor people in river-dwelling communities in West Africa and Latin America. The company made the decision to invest in the development of the medicine under a cloud of uncertainty, not knowing if it would ever become profitable and of any help to the sufferers of the disease. The project has proved to be both profitable and effective in treating the disease. Since the program began in 1987, more than 40 million people annually, in 30 different countries, have benefitted from the medicine, and Merck have committed itself to manufacture and distribute it for as long as river blindness exists. The company and its executives have received praise and recognition for their efforts, although the outcome has depended upon factors well beyond their control. Due to good moral luck, the initial decision to invest and develop the medicine turned into a success story of business ethics and corporate social responsibility. With a negative outcome, the responsible executives would most likely have 
received criticism for wasting the investors' and the owners' money to no avail (Michaelson, 2008).

The research literature acknowledges three main categories of moral luck (Hartman, 2017; Kvalnes, 2017; Nagel, 1979). The most prominent one is resultant moral luck, where the entrepreneur story from the north of Norway and Merck and the river blindness medicine are examples. Then there is constitutive moral luck, which has to do with the elements affecting a person's character. Nature and nurture, genetic heritage and culture, can affect the extent to which a person is respectful, honest, kind, and benevolent in his or her interactions with other people. Good or bad luck play a significant part in the formative processes, yet we tend not to take it into account when praising or blaming people for the character traits they have. The third category goes under the name of situational moral luck, and concerns the moral tests a person faces or avoids, and the extent to which character traits become publicly exposed. A person can be morally fortunate to never face situations where her moral weaknesses are exposed, or morally unfortunate to never get a chance to demonstrate personal courage and honesty, since the situations she faces do not call for the application these moral qualities.

There is room for a fourth category of moral luck, not yet identified or discussed in the studies of this phenomenon. We can call it relational moral luck, and it concerns the social environment a person finds himself or herself in at the time of decision-making. At crucial points in the process of judging and reasoning about what to do, the decision-maker depends on feedback from others, in the form of support or opposition to the ideas that are on the table. In an organization, he or she needs colleagues who intervene and question the assumptions that are present in the reasoning. I return to the concept of relational moral luck in the final chapter of the book, where I dwell more explicitly on the nature of the thought processes that lead from contemplation of options and alternatives, to action, and the extent to which their quality depends on the social side of decision-making.

To what extent does moral luck pose a challenge to the coherence of our moral reasoning? Nagel and Williams thought that they identified a deep tension in the way we think about right and wrong when they introduced the concept (Nagel, 1979; Williams, 1981). Moral luck is no doubt a thought provoking concept and can serve as a reminder that success and failure often depends on factors beyond our own control. However, I do not think the philosophers who launched it actually managed to reveal any 
profound inconsistencies in our moral thinking. Rather, the examples of moral luck indicate that we sometimes mistakenly let actual outcomes affect our evaluations of character and conduct. These evaluations do not appear to survive careful analysis. The considered view we are likely to reach is that success does not justify lying to an investor, that the conduct of the two drunk drivers are equally morally wrong, and that we can judge the Merck initiative to cure river blindness independently of the actual outcome. Moral luck would have been much more troubling if there were tensions between what we take to be the correct evaluations of conduct, and the general assumptions we have about right and wrong. The main value of the concept is that it can serve as a reminder of how outcomes affect our moral judgments and that we have good reasons to correct them when they do.

\section{REFERENCES}

Brandt, R. B. (1959). Ethical theory. Englewood Cliffs, NJ: Prentice-Hall.

Hartman, R. J. (2017). In defense of moral luck: Why luck often affects praiseworthiness and blameworthiness. Taylor \& Francis.

Hartman, R. J. (2018). Moral luck and the unfairness of morality. Philosophical Studies, 1-19.

Kvalnes, Ø. (2017). Fallibility at work: Rethinking excellence and error in organizations. London: Palgrave Macmillan.

Lench, H. C., Domsky, D., Smallman, R., \& Darbor, K. E. (2015). Beliefs in moral luck: When and why blame hinges on luck. British Journal of Psychology, $106(2), 272-287$.

Michaelson, C. (2008). Moral luck and business ethics. Journal of Business Ethics, $83(4), 773-787$.

Nagel, T. (1979). Moral luck. In Mortal questions. Cambridge: Cambridge University Press.

Williams, B. (1981). Moral luck: Philosophical papers 1973-1980. Cambridge: Cambridge University Press.

Zimmerman, M. J. (1987). Luck and moral responsibility. Ethics, 97(2), 374-386. 
Open Access This chapter is licensed under the terms of the Creative Commons Attribution 4.0 International License (http://creativecommons.org/licenses/ by $/ 4.0 /$ ), which permits use, sharing, adaptation, distribution and reproduction in any medium or format, as long as you give appropriate credit to the original author(s) and the source, provide a link to the Creative Commons licence and indicate if changes were made.

The images or other third party material in this chapter are included in the chapter's Creative Commons licence, unless indicated otherwise in a credit line to the material. If material is not included in the chapter's Creative Commons licence and your intended use is not permitted by statutory regulation or exceeds the permitted use, you will need to obtain permission directly from the copyright holder.

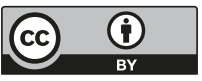

